\title{
Validity of tests performed to diagnose acute abdominal pain in patients admitted at an emergency department
}

\author{
J. A. Navarro Fernández, P. J. Tárraga López ${ }^{1}$, J. A. Rodríguez Montes² and M. A. López Cara ${ }^{3}$ \\ Department of Emergency of Yecla, Murcia. Spain. ${ }^{\prime}$ Medical Center in Albacete. School of Medicine. Albacete, Spain. \\ ${ }^{2}$ Department of Surgery. Autonomous University of Madrid. Spain. ${ }^{3}$ Medical Center in Alcaraz. Albacete, Spain. \\ Autonomous University of Madrid. Spain
}

\begin{abstract}
Objective: to determine the real importance of anamnesis, physical examination, and various tests in the assessment of acute abdominal pain.

Methods: a retrospective observational study with patients complaining of abdominal pain at the Emergency Department, Altiplano Health Area (Murcia) was performed. In our study we considered the following variables: socio-demographic data, history of previous surgery, symptoms, place and type of pain. Imaging tests were labeled as positive, negative, or inconclusive for assumed diagnoses, which were retrospectively assessed by an external radiologist who was unaware of the patient's final diagnosis.

Results: our study includes 292 patients with a mean age of 45.49 years; $56.8 \%$ of these patients were women. Regarding the frequency of the different acute abdomen diagnoses, appendicitis was the main cause (approx. 25\%), followed by cholecystitis (10\%). We found a significant diagnostic correlation between pain location in the right hypochondrium (RHC) and a diagnosis with cholecystitis. This location was also significant for acute appendicitis (up to 74\%). Regarding clinical signs, we only observed a significant correlation between fever and viscera perforation, and between Murphy's sign and cholecystitis. Sensitivity and specificity found in relation to the psoas sign were similar to those seen in other series, 16 and 95\% respectively, and slightly lower than the Blumberg or rebound sign, which we found to be around 50 and $23 \%$, respectively.

Conclusions: a) anamnesis and physical examination offer limited accuracy when assessing acute abdomen; b) ultrasound scans offer a low diagnostic agreement index for appendicitis; and c) laparoscopy may prove useful for diagnosis, and is also a possible treatment for acute abdominal pain despite its low diagnostic efficiency.
\end{abstract}

Key words: Emergency. Abdominal pain. Diagnosis.

\section{Received: 11-12-08.}

Accepted: 12-05-09.

Correspondence: Pedro J. Tárraga López. C/ Ángel, 53, 1 E. 02002 Albacete, Spain.e-mail: pedrojuan.tarraga@uclm.es
Navarro Fernández JA, Tárraga López PJ, Rodríguez Montes JA, López Cara MA. Validity of tests performed to diagnose acute abdominal pain in patients admitted at an emergency department. Rev Esp Enferm Dig 2009; 101: 610-68.

\section{INTRODUCTION}

Abdominal pain is one of the most frequent symptoms in patients attended at the Emergency Department, and constitutes almost $50 \%$ of the reasons for going to a hospital's A+E. Half of patients with abdominal pain attended to in an emergency room remain undiagnosed (1).

The term 'acute abdomen' was introduced into the medical literature by John B Deaver, who described it as: "any acute intra-abdominal trouble that requires urgent surgical treatment". In 1921, Sir Zachary Cope pointed out the importance of preparing an anamnesis and doing a thorough physical examination. Those attitudes that do not consider immediate action when faced with possible acute abdominal trouble are only justified under exceptional circumstances. Cope went on to stress that not making a decision within 8 or 10 hours may imply endangering the patient's life, and that a delay of 2 hours is equivalent to between 2 weeks and 2 months for the patient to recover. Moreover, a few standard techniques are sufficient to confirm a clinical diagnosis in the case of acute abdomen (2).

We may define acute abdomen as the presence of abdominal pain that has evolved in less than a week and remains undiagnosed. This pain is characterized by: a) its originating from and referring to the abdomen; $b$ ) its being acute given its chronology and intensity; c) its being accompanied by intestinal passage disturbances; and d) severe deterioration of the patient's overall health status. 
Acute abdominal pain represents $10 \%$ of consultations in a hospital's emergency service (3). Although there are numerous causes for acute abdominal pain, there is a group of such causes that appears most frequently. Therefore, we consider them first when we examine a patient. In an analysis of 10,682 cases of acute abdominal pain followed by the World Gastroenterology Organization, $34 \%$ were diagnosed as nonspecific abdominal pain, $28 \%$ as acute appendicitis, and $10 \%$ as cholecystitis (4).

The main causes of acute abdominal pain requiring urgent treatment may be summarized as follows: acute appendicitis, abdominal aorta aneurysm, hollow viscera perforation, obstructed intestine with or without strangulation, intestinal ischemia, cholecystitis and acute cholangitis, rupture of ectopic pregnancy, intra-abdominal abscess, hepatic rupture, ruptured spleen and extra-abdominal pathology. These causes also depend on the patient's sex and age (5) (Table I).

The main objective of this study was to determine the real importance of the anamnesis, physical examination, and the various laboratory tests to assess acute abdominal pain. The second objective was to know the percentage of patients who take painkillers during the acute process (6), and of patients who return for the same cause within 10 days after being discharged from a hospital emergency room.

\section{MATERIAL AND METHODS}

This is an observational, retrospective study which we carried out in a population from the "Altiplano Health Area V", Yecla (Murcia). Inclusion criteria were based on patients who came to our hospital emergency room complaining of abdominal pain during the period between January first 2004 and December $31^{\text {st }} 2004$. We randomly selected a sample of 300 patients which we homogeneously divided into two groups: a) patients who had not been hospitalized; and b) patients who had been admitted to our General Surgery Service and had been diagnosed with non-traumatic acute abdomen. We excluded eight patients in whom the necessary studies to reach a definite diagnosis had not been completed. Therefore, our study sample consisted of 292 patients.

Samples were selected from the hospital's admission registry database, and that of the Emergency Department, which includes data such as reason for consultation and diagnosis at discharge. We reviewed case histories, and collected socio-demographic data, histories of previous surgery, associated symptoms, and location and type of pain. The doctor doing the physical examination considered whether there were any general clinical signs (hypotension/hypoperfusion, tachycardia, and temperature), as well as any clinical signs when examining the patient's abdomen: presence or absence of abdominal distension, palpable masses, pulsatile masses, as well as various signs of irritated peritoneum (7).
Complementary imaging tests were labeled positive, negative, and inconclusive for the assumed diagnosis, and were reassessed later by an external radiologist who was unaware of the patient's final diagnosis (8). The analysis for agreement and efficacy between clinical diagnosis (patient's history/laboratory tests) and laparascopic/laparotomic diagnosis was performed after considering the laparoscopic/laparotomic finding as a true criterion, which in turn refuted the pathological diagnosis (9).

\section{Operational definitions}

Anamnesis, physical examination, and tests form part of the diagnosis procedure. Evidently, a good diagnostic test offers positive results in patients and negative results in the healthy population. Therefore, the following parameters must be expected of such a test (10):

-Validity: the extent to which a test measures what it ought to measure. Sensitivity and specificity are measurements of this validity.

-Reproducibility: the capacity of the test to offer the same results when applying the test again under similar circumstances.

-Safety: determined by a predictive value of a positive or a negative result.

It is advisable that the test be easy to perform, accepted by patients, with a minimum of potential adverse effects, and economically feasible.

In this study, we will fundamentally review the concepts that determine the validity of a test (sensitivity and specificity), and its safety (positive and negative predictive values) using the Kappa index ( $\kappa$ ) for agreement.

We used SPSS, version 11.0, for data analyses and to determine the frequency of study variables. We carried out and calculated data analyses with CASPe (11). This was also used to calculate agreement, Kappa value, and the rest of diagnostic efficacy indices by applying a 95\% level of confidence $(\alpha<0.05)(12-18)$.

\section{RESULTS}

The number of patients studied was 292, with a mean age of 45.49 years, of whom $56.8 \%$ were women. In terms of frequency of the various causes of acute abdomen, appendicitis was found to be the main cause with a percentage of around $25 \%$, followed by cholecystitis with a frequency of $10 \%$. A laparoscopy was done in approximately $45 \%$ of patients, and was the main procedure in almost $75 \%$ of them. Up to $9 \%$ of these patients were diagnosed after performing various diagnostic tests, including laparoscopy for nonspecific abdominal pain (Fig. 1). 


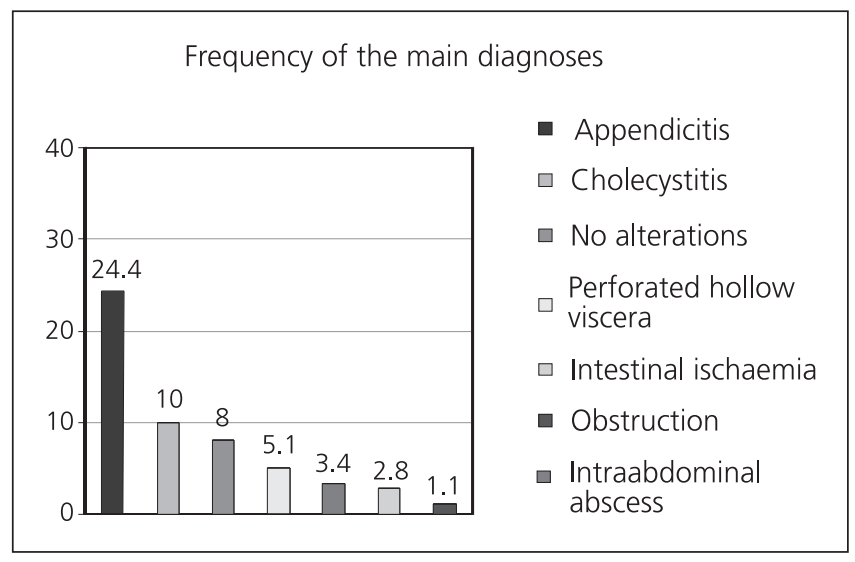

Fig. 1. Main diagnoses.

Principales diagnósticos y sus frecuencias.

Pain location in the right lower quadrant of the abdomen may relate to acute appendicitis with an accuracy of $76.5 \%$, a Jouden index of 0.6, a likelihood ratio (CPP or LR+) of 5.98, and a 95\% CI (2.03-17.68). The relationship between pain in the right upper quadrant and cholecystitis increased considerably with an LR+ of 26.14 and a 95\% CI (6.47-105).

Although there was no diagnostic agreement between fever and acute appendicitis, it did exist in relation to perforated hollow viscera with an LR+ of 5.7 and a 95\% CI (1.848.9).

The presence of signs of irritated peritoneum did not correlate with the presence of appendicitis. All the results analyzed had an LR+ close to one, or included a 95\% CI. On the other hand, a significant relationship was observed between the presence of Murphy's sign and acute cholecystitis with an LR+ of 21.50 and a 95\% CI (1.99273.73).

Regarding laboratory tests, the relationship between leukocytosis and appendicitis was minor, with an LR+ of 2.10 and a $95 \%$ CI (1.27-3.50).

When we analyzed imaging tests, plain X-rays show a moderate relationship with perforated hollow viscera with an LR+ of 5.17 and a 95\% CI (1.71-15.58), and with intestinal ischemia with an LR+ of 10.83 , 95\% CI (5.0523.33). However, abdominal X-rays while standing reveals a moderate relationship with perforated hollow viscera, with an LR+ of 6.20, 95\% CI (1.48-25.96). Abdominal ultrasounds show a significant relationship with cholecystitis [LR+ 4.69, 95\% CI (2.90-7.60)]. Neither ultrasounds nor CAT show diagnostic agreement with the remaining conditions (Table I).

In order to determining diagnostic agreement among the various tests, we have to point out that the agreement and Kappa index observed among the various diagnostic tests revealed a moderate degree of correlation that differed considerably from the unit (Figs. 2, 3 and 4).

The correlation obtained among the various diagnostic tests and laparoscopy was poor, as it was in relation to the gold standard (pathology confirmation), which rendered it sensitive, but inefficient in terms of specificity to rule out the pathology in question, thus facilitating the appearance of a considerable amount of false negatives.

The Kappa index for interobserver variability in the diagnostic assessment of imaging tests was 0.7 , which is considered a good diagnostic correlation.

A rectal examination was done in only $6.3 \%$ of patients attended in our Emergency Department and a good diagnostic correlation was found in more than $50 \%$ of patients undergoing this examination.

Table I

\begin{tabular}{|c|c|c|c|c|c|c|}
\hline & $\begin{array}{l}\text { Location } \\
\text { right lower } \\
\text { quadrant } \\
\text { Acute } \\
\text { appendicitis }\end{array}$ & $\begin{array}{l}\text { Location } \\
\text { right upper } \\
\text { quadrant } \\
\text { Cholecystitis }\end{array}$ & $\begin{array}{l}\text { Appendicitis } \\
\text { leukocytosis }\end{array}$ & $\begin{array}{l}\text { Obstruction- } \\
\text { abdominal } \\
\text { X-ray }\end{array}$ & $\begin{array}{l}\text { Ultrasound } \\
\text { cholecystitis }\end{array}$ & $\begin{array}{l}\text { Cholecystitis- } \\
\text { Murphy's sign }\end{array}$ \\
\hline Sensitivity & $\begin{array}{l}69.04 \% \\
55.06 \text { to } 83.02 \%\end{array}$ & $85.71 \%$ & $\begin{array}{l}81.0 \% \\
66.7 \text { to } 90.0 \%\end{array}$ & $\begin{array}{l}50.0 \% \\
18.8 \text { to } 81.2 \%\end{array}$ & $\begin{array}{l}100.0 \% \\
64.6 \text { to } 100.0 \%\end{array}$ & $\begin{array}{l}50.0 \% \\
9.5 \text { to } 90.5 \%\end{array}$ \\
\hline Specificity & $\begin{array}{l}88.46 \% \\
76.18 \text { to } 100.74 \%\end{array}$ & $\begin{array}{l}96.72 \% \\
92.25 \text { to } 101.19 \%\end{array}$ & $\begin{array}{l}61.5 \% \\
42.5 \text { to } 77.6 \%\end{array}$ & $\begin{array}{l}90.3 \% \\
80.5 \text { to } 95.5 \%\end{array}$ & $\begin{array}{l}78.7 \% \\
66.9 \text { to } 87.1 \%\end{array}$ & $\begin{array}{l}97.7 \% \\
87.9 \text { to } 99.6 \%\end{array}$ \\
\hline Positive predictive value & $\begin{array}{l}90.62 \% \\
80.52 \text { to } 100.72 \%\end{array}$ & $\begin{array}{l}75.0 \% \\
44.99 \text { to } 105.00 \%\end{array}$ & $\begin{array}{l}77.3 \% \\
63.0 \text { to } 87.2 \%\end{array}$ & $\begin{array}{l}33.3 \% \\
86.1 \text { to } 19.5 \%\end{array}$ & $\begin{array}{l}35.0 \% \\
18.1 \text { to } 56.7 \%\end{array}$ & $\begin{array}{l}50.0 \% \\
9.5 \text { to } 90.5 \%\end{array}$ \\
\hline Negative predictive value & $\begin{array}{l}63.88 \% \\
48.19 \text { to } 79.57 \%\end{array}$ & $\begin{array}{l}98.33 \% \\
95.09 \text { to } 101.57 \%\end{array}$ & $\begin{array}{l}66.7 \% \\
46.7 \text { to } 82.0 \%\end{array}$ & $\begin{array}{l}94.9 \% \\
86.1 \text { to } 19.5 \%\end{array}$ & $\begin{array}{l}100.0 \% \\
92.6 \text { to } 100.0 \%\end{array}$ & $\begin{array}{l}97.7 \% \\
87.9 \text { to } 99.6 \%\end{array}$ \\
\hline $\begin{array}{r}\text { Positive likelihood } \\
\text { coefficient (CP+) }\end{array}$ & $\begin{array}{l}5.98 \\
2.02 \text { to } 17.68\end{array}$ & $\begin{array}{l}26.14 \\
6.47 \text { to } 105.60\end{array}$ & $\begin{array}{l}2.10 \\
1.27 \text { to } 3.50\end{array}$ & $\begin{array}{l}5.17 \\
1.71 \text { to } 15.58\end{array}$ & $\begin{array}{l}4.69 \\
2.90 \text { to } 7.60\end{array}$ & $\begin{array}{l}21.50 \\
1.99 \text { to } 232.73\end{array}$ \\
\hline $\begin{array}{l}\text { Negative likelihood } \\
\text { coefficient (CP-) }\end{array}$ & $\begin{array}{l}0.34 \\
0.21 \text { to } 0.56\end{array}$ & $\begin{array}{l}0.14 \\
0.02 \text { to } 0.90\end{array}$ & $\begin{array}{l}0.31 \\
0.16 \text { to } 0.60\end{array}$ & $\begin{array}{l}0.55 \\
0.24 \text { to } 1.27\end{array}$ & & $\begin{array}{l}0.51 \\
0.13 \text { to } 2.08\end{array}$ \\
\hline
\end{tabular}




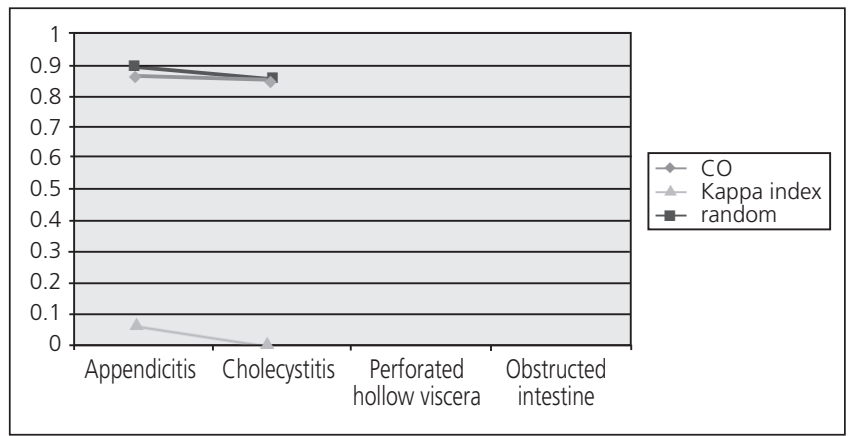

Fig. 2. Agreement and the Kappa index observed between the pathological diagnosis and laparoscopy.

Concordancia observada e índice Kappa entre el diagnóstico AP y laparoscopia.

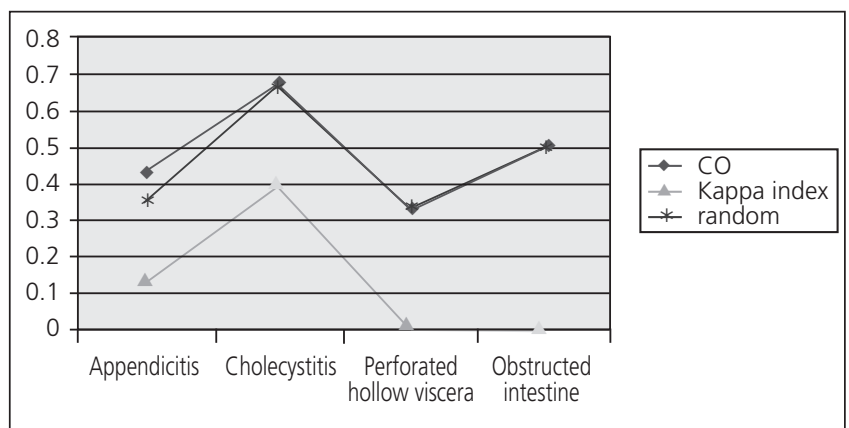

Fig. 3. Agreement and Kappa index observed between ultrasonography and laparoscopy.

Concordancia observada e índice kappa entre ecografía y laparoscopia.

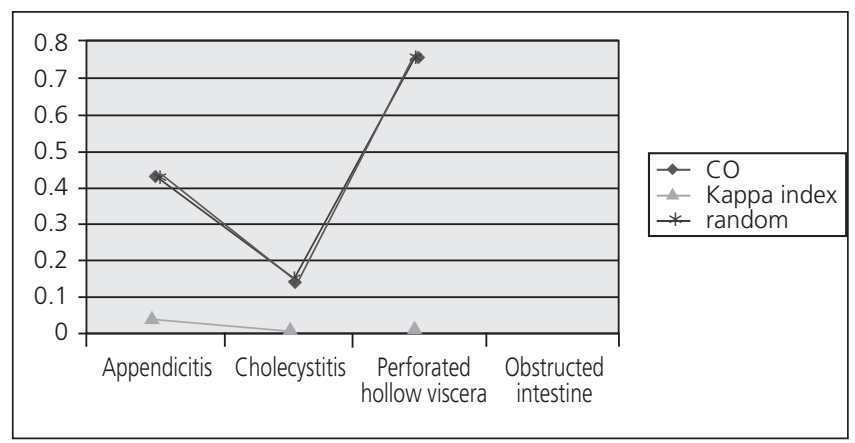

Fig. 4. Agreement and Kappa index observed between pathological diagnosis and laparotomy.

Concordancia observada e índice Kappa entre diagnóstico AP y laparotomía.

The percentage of patients who returned for the same cause within 10 days after being discharged from the hospital emergency department was around $2.4 \%$, and in no patient, the history or diagnosis at discharge was modified.

\section{DISCUSSION}

The main causes of acute abdominal pain found in our study are acute appendicitis, nonspecific abdominal pain, and biliary tract diseases. The literature we reviewed not only includes biliary tract diseases as the main cause of such pain (13), but also nonspecific abdominal pain or abdominal pain of unknown origin as one of the most common final diagnoses (14), which also comes across in our study. In terms of etiologic distribution, however, we note differences in relation to diverticular disease, nonspecific abdominal pain, appendicitis, neoplasms and intestinal obstruction, which are noted much more frequently in the literature than in this study (19).

We also observe a significant diagnostic agreement between the location of pain in the right upper quadrant and the diagnosis of cholecystitis. However, in the literature, only $38 \%$ of cases of cholecystitis, the pain was confined to the right upper quadrant. This location of pain is also significant in the case of acute appendicitis since up to $74 \%$ of patients had pain confined to the right lower quadrant at the time of emergency room admissions $(20,21)$.

With regard to the correlation with other symptoms, we noted no significant differences. In a large series, $100 \%$ of patients with appendicitis, cholecystitis and intestinal obstruction complained of pain followed by vomiting, in contrast with 20 and $24 \%$ of patients with nonspecific abdominal pain and gastroenteritis, respectively. Other studies also support this fact and fever and vomiting are more common in patients with acute appendicitis than in those with other causes of acute abdomen $(22,23)$.

With respect to clinical signs, we have only found a significant correlation between fever and perforated hollow viscera, and between Murphy's sign and acute cholecystitis. The sensitivity and specificity found with respect to the psoas sign are very similar to those observed in other series, around the 16 and $95 \%$, respectively. These percentages are somewhat lower in terms of Blumberg's or rebound sign that in our study are around 50 and $23 \%$, respectively (24).

The main indication for white blood count and differential is the discrimination between acute appendicitis and nonspecific abdominal pain. Indeed, leukocytosis accompanies acute appendicitis in most cases, less in cholecystitis and about half of cases of obstruction, compared with gastroenteritis by $43 \%$ and nonspecific abdominal pain in $31 \%$ (25).

With regard to imaging tests, ultrasound scans provide an accurate diagnosis for acute cholecystitis in 95 to $99 \%$ of cases, and for appendicitis being lower, around $76 \%$ (25).

The correlation among the various diagnostic tests and laparoscopy is poor, as well as between latter and the gold standard (pathological confirmation). Therefore, despite being sensitive, it is not efficient in terms of specificity to rule out the pathology in question, thus facilitat- 
ing the appearance of a considerable number of false negatives. Laparoscopy may be a useful tool for diagnosis, and possibly treatment of acute abdominal pain; although its efficiency was somewhat low in our study, but not in other series (26).

The standard reference used (pathology findings on the surgical specimen) may only be verified in patients undergoing surgery, which may possibly imply a sequence bias (or verification bias). A sequence bias is usual when the reference pattern is an invasive technique, and it is more likely to take place when the diagnostic test is positive (an abdominal ultrasonogram suggesting appendicitis). The reliability of diagnostic tests is only assessed for imaging techniques, and the same process is not taken into account for physical examination (27).

\section{CONCLUSIONS}

1. Patient's history and physical examination are of limited accuracy when assessing acute abdominal pain.

2. An ultrasound scan presents a low diagnostic agreement index in relation to appendicitis.

3. Laparoscopy may prove useful to diagnose, and possibly treatment, acute abdominal pain despite a low diagnostic efficiency.

\section{REFERENCES}

1. Moya Mir MS, Laguna P. Analgesia en el dolor abdominal agudo. Estal Emergencias 2001; 13: 229-31.

2. Schwartz SI. Apéndice. In: Schwartz SI, Shires GT, Spencer FC, editors. Principios de Cirugía. $6^{\text {th }}$ ed. México: McGraw-Hill; 2000.

3. Wolfe JM, Lein DY, Lenkoski K, Smithline HA. Analgesic administration to patients with an acute abdomen: a survey of emergency medicine physicians. Am J Emerg Med 2000; 18(3): 250-3.

4. Abboud PA, Colwell CB. Critically reappraising the literature-driven practice of analgesia administration for acute abdominal pain in the emergency room prior to surgical evaluation. Am J Surg 2004; 188(1): 102-3.

5. Dombal FT. Acute abdominal pain in the elderly. J Clin Gastroenterol 1994; 19: 331-5.

6. Nissman SA, Kaplan LJ, Mann BD. Critically reappraising the literature-driven practice of analgesia administration for acute abdominal pain in the emergency room prior to surgical evaluation. Am J Surg 2003; 185(4): 291-6.

7. Yen K, Karpas A, Pinkerton HJ, Gorelick MH. Interexaminer reliability in physical examination of pediatric patients with abdominal pain. Arch Pediatr Adolesc Med 2005; 159(4): 373-6.

8. López de Ullibarri GI, Pita FS. Metodología de la investigación. Me- didas de concordancia: el índice Kappa. HTML Febrero 2002: 16971.

9. Gil VF, Peinado E, Obrador E, Pascual R, Pérez C, Merino J. Validez de las pruebas diagnósticas para confirmar o descartar una apendicitis aguda. Med Clin (Barc) 2000; 114(Supl. 2): 48-51.

10. Sackett DL, Haynes RB, Guyatt GH, Tugwell P. Epidemiología clínica. Ciencia básica para la medicina clínica. $2^{\mathrm{a}}$ ed. Madrid: Editorial Médica Panamericana; 1994. P. 131-56.

11. Jiménez Rodríguez RM, Díaz Pavón JM, Vázquez Monchul JM, Socas Macías M, Sánchez Gil JM. Causa infrecuente de dolor abdominal: Ewing's sarcomasarcoma de Ewing. Rev Esp Enferm Dig 2007; 99(12): 734-6

12. Menduiña Guillén MJ, Alaminos García P, Valenzuela Barranco M. Paciente de 70 años con dolor en fosa ilíaca izquierda y crepitación a la palpación profunda abdominal. Rev Esp Enferm Dig 2007; 99(10): 606-7.

13. CASPe. Programa de habilidades en lectura crítica España. Disponible en: http://www.redcaspe.org/herramientas/descargas/pruebasdiagnosticas.xls

14. López de Ullibarri GI, Pita FS. Metodología de la investigación. Medidas de concordancia: el índice Kappa. HTML Febrero 2002: 16971.

15. Soto-López A, Águila-Melero O, Reyes-Corcho A, Consuegra-Díaz JE, Gómez-Baute R. Eficiencia diagnóstica en la apendicitis aguda. Cir Ciruj 2003; 71(3): 204-9.

16. Aydelotte JD, Collen JF, Martin RR. Analgesic administration prior to surgical evaluation for acute appendicitis. Curr Surg 2004; 61(4): 373-5.

17. Kettunen J, Paajanen H, Kostiainen S. Emergency abdominal surgery in the elderly. [Abstract]. Hepatogastroenterology 1995; 42: 106-8.

18. Larraona JL, Castro M. Dolor torácico de origen esofágico. Rev Esp Enferm Dig 2007; 99(4): 239.

19. Díaz-Rubio, M. Chest pain of esophageal origin. Rev Esp Enferm Dig 2004; 96(9): 593-8.

20. Planells Roig M, Bueno Lledó J, Sanahuja Santafé A, García Espinosa R. Quality of life (GIQLI) and laparoscopic cholecystectomy usefulness in patients with gallbladder dysfunction or chronic nonlithiasic biliary pain (chronic acalculous cholecystitis). Rev Esp Enferm Dig 2004; 96(7): 442-51.

21. Wagner JM, McKinney WP, Carpenter JL. Does this patient have appendicitis? JAMA 1996; 276(19): 21-5.

22. Eskelinen M, Ikonen J, Lipponen P. The value of history-taking, phisical examination, and computer assistance in the diagnosis of acute appendicitis in patients more than 50 years old. Scand J Gastroenterol 1995; 30: 349-55.

23. Stalinad JR, Ditchbrun J, De Dombal FT. Clinical presentation of acute abdomen: Study of 600 patients. Br Med J 1972; 3: 393-8.

24. Kim J-P, Kim S-J, Lee J-H, Kim S-W, Choi M-G, Yu H-J. Surgery in the aged in Korea. Arch Surg 1998; 133: 18-23.

25. Gil VF, Peinado E, Obrador E, Pascual R, Pérez C, Merino J. Validez de las pruebas diagnósticas para confirmar o descartar una apendicitis aguda. Med Clin (Barc) 2000; 114(Supl. 2): 48-51.

26. Zimmerman O, Halpern P. Opinion survey of analgesia for abdominal pain in Israeli emergency departments. Isr Med Assoc J 2004; 6(11): 681-5.

27. González de Diosa J, Ochoa Sangradorb C. Rendimiento de la ecografía abdominal en el diagnóstico de apendicitis aguda. La importancia del cociente de probabilidades. An Pediatr (Barc) 2003; 59(6): 601-5. 


\title{
Validez de las pruebas diagnósticas realizadas a pacientes con dolor abdominal agudo en un servicio de urgencias hospitalario
}

\author{
J. A. Navarro Fernández, P. J. Tárraga López ${ }^{1}$, J. A. Rodríguez Montes ${ }^{2}$ y M. A. López Cara ${ }^{3}$ \\ Servicio de Urgencias de Yecla, Murcia. ${ }^{I}$ Centro de Salud de Albacete. Facultad de Medicina de Albacete. \\ ${ }^{2}$ Departamento de Cirugía. Universidad Autónoma de Madrid. ${ }^{3}$ Centro de Salud de Alcaraz. Albacete. Universidad \\ Autónoma de Madrid
}

\begin{abstract}
RESUMEN
Objetivo: determinar la importancia real que en sí tienen la anamnesis, la exploración física y las diferentes pruebas complementarias en la valoración del dolor abdominal agudo.

Métodos: estudio observacional y retrospectivo en una población a estudio: Área V de Salud - Altiplano (Murcia). Enfermos que consultan por dolor abdominal en el Servicio de Urgencias. Se realiza una revisión de las historias clínicas. Variables a estudio: datos socio-demográficos, antecedentes personales de cirugía previa, síntomas asociados, localización del dolor y tipo del mismo. Las pruebas complementarias de imagen se etiquetaron como positivas, negativas y no concluyentes para el diagnóstico de presunción y fueron a posteriori reevaluadas por un radiólogo externo que desconocía el diagnóstico final del enfermo.
\end{abstract}

Resultados: el número de pacientes estudiados fue de 292, cuya edad media estuvo en los 45,49 años. El 56,8\% fueron mujeres. En cuanto a la frecuencia de los diferentes diagnósticos de abdomen agudo podemos hablar de la apendicitis como principal causa con un porcentaje cercano al 25\%, seguido de la colecistitis con un 10\%. Encontramos una concordancia diagnóstica significativa entre la localización del dolor en $\mathrm{HCD}$ y el diagnóstico de colecistitis. Esta localización también resulta significativa en el caso de la apendicitis aguda, en esta, hasta un 74\%. En cuanto a los signos clínicos sólo hemos encontrado una correlación significativa entre la fiebre y la perforación de víscera hueca y entre el signo de Murphy y la colecistitis. La sensibilidad y especificidad encontradas con respecto al signo del psoas son muy similares a las encontradas en otras series entorno al 16 y $95 \%$ respectivamente; siendo algo menores con respecto al Blumberg o signo de rebote que se sitúa en nuestro estudio entorno al 50 y $23 \%$.

Conclusiones: a) la anamnesis y la exploración física tienen una exactitud limitada a la hora de valorar abdomen agudo; b) la ecografía presenta con respecto a la apendicitis un índice de concordancia diagnóstica bajo; y c) la laparoscopia puede resultar un instrumento útil para el diagnóstico y posible tratamiento del dolor abdominal agudo, aunque la eficiencia diagnóstica que determinaría su utilización sea baja.

Palabras clave: Urgencias. Dolor abdominal. Diagnóstico.

\section{INTRODUCCIÓN}

El dolor abdominal es uno de los síntomas por el que con más frecuencia acude el paciente a Urgencias, consti- tuyendo cerca del $50 \%$ de los motivos de consulta en servicio de urgencias hospitalario. La mitad de estos dolores abdominales que acuden a urgencias quedan sin diagnóstico (1).

El término abdomen agudo fue introducido en la literatura médica por John B. Deaver como "cualquier afección aguda intraabdominal que necesita tratamiento quirúrgico urgente”. En 1921, Sir Zachary Cope señaló la importancia de realizar una anamnesis y un examen físico cuidadoso. Las actitudes de espera frente a un posible abdomen agudo sólo excepcionalmente están justificadas. No tomar decisiones en 8 ó 10 horas, señala Cope, es poner en peligro la vida del enfermo. Una demora de 2 horas equivale de 2 semanas a 2 meses en la recuperación del paciente. Además, en caso del abdomen agudo basta con unas pocas técnicas estandarizadas para confirmar el diagnóstico clínico (2).

Podemos definir el abdomen agudo como la presencia de un dolor abdominal hasta entonces no diagnosticado y que tiene una evolución inferior a una semana. Se trata de un dolor caracterizado por: a) ser originado y referido al abdomen; b) agudo por su cronología e intensidad; c) acompañado de alteraciones del tránsito intestinal; y d) deterioro grave del estado general.

El dolor abdominal agudo supone el 10\% de las consultas en servicios de urgencias (3). Aunque son múltiples las causas de dolor abdominal agudo, hay un grupo de ellas que son más frecuentes y por tanto son en ellas en las que hemos de pensar en primer lugar cuando valoramos al paciente. En un análisis de 10.682 casos de dolor abdominal agudo seguidos por la Organización Mundial de Gastroenterología, el 34\% fueron diagnosticados como dolor abdominal inespecífico, un $28 \%$ de apendicitis aguda y un $10 \%$ de colecistitis (4).

Las principales afecciones causantes de dolor abdominal agudo y que precisan un tratamiento urgente se pueden resumir en: apendicitis aguda, aneurisma de la aorta abdominal, perforación de víscera hueca, obstrucción intestinal con o sin estrangulación, isquemia intestinal, colecistitis y colangitis aguda, rotura de embara- 
zo ectópico, absceso intraabdominal, rotura hepática, rotura de bazo y patología extraabdominal; aunque depende de la edad y sexo del paciente (5) (Tabla I).

Analizado lo presente, el objetivo principal del presente estudio es determinar la importancia real que en sí tienen la anamnesis, la exploración física y las diferentes pruebas complementarias en la valoración del dolor abdominal agudo, así como objetivo secundario conocer el porcentaje de enfermos con tratamiento analgésico durante el proceso agudo (6) y el de pacientes que dados de alta del servicio de urgencias consultan por el mismo motivo en los siguientes 10 días.

\section{MATERIAL Y MÉTODOS}

Se trata de un estudio observacional y retrospectivo, con una población de estudio localizada en el Área V de Salud de Altiplano Yecla (Murcia), con unos criterios de inclusión basado en enfermos que consultan por dolor abdominal en el Servicio de Urgencias del hospital durante el periodo comprendido entre el 01/01/04 y el 31/12/04, seleccionándose aleatoriamente una muestra total de 300 pacientes, conformada en dos grupos homogéneos, uno que pasó por servicio de urgencias sin requerir ingreso y otro que ingresó en Servicio de Cirugía General con diagnóstico de abdomen agudo no traumático. Se excluyeron 8 pacientes debido a que no se habían completado los estudios necesarios para llegar a un diagnóstico, quedando una población final de 292 pacientes.

Las muestras se seleccionaron a partir de la base de datos que recoge las altas hospitalarias y la del propio servicio de urgencias, en la que se recoge el motivo de consulta y el diagnóstico al alta del mismo. Realizamos una revisión de las historias clínicas de estos enfermos, extrayendo datos sociodemográficos, antecedentes personales de cirugía previa, síntomas asociados, localización del dolor y tipo del mismo. Dentro del examen físico se tuvieron en cuenta la presencia o no de signos clínicos generales (hipotensión/hipoperfusión, taquicardia y fiebre), así como signos clínicos de la exploración abdominal: la presencia o ausencia de distensión abdominal, masas palpables, masas pulsátiles, así como diferentes signos de irritación peritoneal (7).

Las pruebas complementarias de imagen se etiquetaron como positivas, negativas y no concluyentes para el diagnóstico de presunción y fueron a posteriori reevaluadas por un radiólogo externo que desconocía el diagnóstico final del enfermo (8). El análisis de concordancia y de eficiencia entre el diagnóstico clínico (historia clínica/pruebas complementarias), y el diagnóstico laparoscópico/laparotómico se realizó considerando como criterio de verdad el hallazgo laparoscópico/laparotómico y este a su vez refutando el diagnóstico anatomopatológico (9).

\section{Definiciones operacionales}

En las fases del proceso diagnóstico intervienen la historia clínica, la exploración física y la realización de pruebas complementarias. Es evidente que una buena prueba diagnóstica es la que ofrece resultados positivos en enfermos y negativos en sanos. Por lo tanto, las condiciones que deben ser exigidas a un test son (10):

-Validez: es el grado en que un test mide lo que se supone que debe medir. La sensibilidad y la especificidad son medidas de su validez.

-Reproductividad: es la capacidad del test para ofrecer los mismos resultados cuando se repite su aplicación en circunstancias similares.

-Seguridad: la seguridad viene determinada por el valor predictivo de un resultado positivo o negativo.

Es conveniente que el test sea sencillo de aplicar, aceptado por los pacientes, tenga los mínimos efectos adversos posibles y sea económicamente soportable.

En este estudio se revisarán fundamentalmente los conceptos que determinan la validez de un test (sensibilidad y especificidad) y su seguridad (valores predictivos positivos y negativos), usándose el índice Kappa (к) como índices de concordancia.

Para el tratamiento de los datos se utilizó en SPSS 11.0, facilitando la determinación de la frecuencia de las variables a estudiar. Los análisis de los datos fueron ejecutados y calculados mediante el soporte informático de CASPe (11). Se usó también para el cálculo de la concordancia, valor Kappa y el resto de los índices de eficacia diagnóstica, trabajándose con un nivel de confianza de $95 \%(\alpha<0,05)(12-18)$.

\section{RESULTADOS}

El número de pacientes estudiados fue de 292, cuya edad media estuvo en los 45,49 años. El 56,8\% fueron mujeres. En cuanto a la frecuencia de los diferentes diagnósticos de abdomen agudo podemos hablar de la apendicitis como principal causa con un porcentaje cercano al $25 \%$, seguido de la colecistitis con un $10 \%$. Se realizó laparoscopia en alrededor de un $45 \%$ de los enfermos, siendo este el procedimiento principal en casi tres cuartas partes de los mismos. Hasta en $9 \%$ de estos enfermos fueron diagnosticados tras diferentes pruebas diagnósticas, incluyendo la laparoscopia de dolor abdominal inespecífico (Fig. 1).

La localización del dolor en fosa iliaca derecha establece una pequeña relación con respecto a la apendicitis aguda, presentando una exactitud de 76,5\%, siendo el índice J de Jouden de 0,6 y la razón de verosimilitud (CPP o LR+) de 5,98 con un IC al 95\% $(2,03-17,68)$. Con respecto a la relación entre la localización del dolor en hipocondrio y la colecistitis esta presenta un incremento amplio con LR+ de 26.14 con IC al $95 \%$ (6,47-105). 
No existe concordancia diagnóstica entre la fiebre y apendicitis aguda, aunque sí se presenta esta, con respecto a perforación de víscera hueca $\mathrm{LR}+$ de 5,7 con IC 95\% $(1,8-48,9)$.

La presencia de signos de irritación peritoneal no se correlaciona con la presencia de apendicitis, todos los resultados analizados llevan a una LR+ cercana a uno, o que incluyen el mismo con IC 95\%; sí existe por el contrario una relación importante entre la presencia de signo de Murphy y colecistitis aguda con una LR+ de 21,50 con IC 95\% (1,99-273,73).

Con respecto a determinaciones analíticas, la relación de leucocitosis y apendicitis es pequeña, el LR+ se sitúa en 2,10 con IC $95 \%(1,27-3,50)$.

Si nos centramos en pruebas de imagen, la radiología simple de abdomen presenta una relación moderada con la perforación de víscera hueca situándose el LR+ en 5,17 con IC $95 \%(1,71-15,58)$ y la isquemia intestinal LR+ 10,83 con IC $95 \%(5,05-23,33)$, por otro lado la radiología de abdomen en bipedestación presenta una relación moderada con la perforación de víscera hueca situándose en LR+ 6,20 con IC 95\% (1,48-25,96). La ecografía abdominal presenta un relación significativa con respecto a la colecistitis con LR+ 4,69 IC 95\% (2,90-7,60). Ni la ecografía ni el TAC presentan concordancia diagnóstica con el resto de patologías (Tabla I).

Con respecto a la determinación de la concordancia diagnóstica entre las diferentes pruebas tenemos que señalar que la concordancia observada y el índice de Kappa entre las diferentes pruebas diagnósticas muestran un grado de correlación discreto que difiere mucho de la unidad (Figs. 2, 3 y 4).

La correlación obtenida entre los diferentes pruebas diagnósticas y la laparoscopia es deficiente, así como esta con respecto al gold estándar (confirmación AP), hacién- dola sensible, pero ineficiente en cuanto a su especificidad para descartar la patología en cuestión, facilitando la aparición de falsos negativos en cantidad considerable.

El índice Kappa para la variabilidad interobservador en la valoración diagnóstica de pruebas de imagen se sitúo en 0,7 , lo que traduce una buena correlación diagnóstica.

Sólo en el 6,3\% de los enfermos que consultaron en el servicio de urgencias se realizó tacto rectal para orientar el diagnóstico, presentando una buena correlación diagnóstica en más del $50 \%$ de estos pacientes a los que se les practicó.

El porcentaje de enfermos que dados de alta del servicio de urgencias consultaron por el mismo motivo en los siguientes 10 días se situó en torno al 2,4\%, no presentado ninguno de ellos modificación alguna en la historia clínica ni en el diagnóstico al alta.

\section{DISCUSIÓN}

Las principales causas de dolor abdominal agudo encontradas fueron, la apendicitis aguda, el dolor abdominal inespecífico y las enfermedades del tracto biliar. La enfermedad del tracto biliar es descrita como la principal causa en la literatura revisada (13); así mismo se describe al dolor abdominal inespecífico o de origen indeterminado como uno de los diagnósticos finales más comunes (14), como ocurre en nuestro estudio. Sin embargo, en cuanto a la distribución etiológica se encuentran diferencias frente a enfermedad diverticular, dolor abdominal inespecífico, apendicitis, neoplasias y obstrucción intestinal que en la literatura tienen una presentación mucho más frecuente que la encontrada en el presente (19).

Tabla I

\begin{tabular}{|c|c|c|c|c|c|c|}
\hline & $\begin{array}{l}\text { Localización } \\
\text { FID-apendicitis } \\
\text { aguda }\end{array}$ & $\begin{array}{l}\text { Localización } \\
\text { HCD-colecistitis }\end{array}$ & $\begin{array}{l}\text { Apendicitis } \\
\text { leucos }\end{array}$ & $\begin{array}{l}\text { Obstrucción- } \\
\text { Rx abdomen }\end{array}$ & Eco-colecistitis & $\begin{array}{l}\text { Colecistitis- } \\
\text { Murphy }\end{array}$ \\
\hline Sensibilidad & $\begin{array}{l}69,04 \% \\
55,06 \text { a } 83,02 \%\end{array}$ & $85,71 \%$ & $\begin{array}{l}81,0 \% \\
66,7 \text { a } 90,0 \%\end{array}$ & $\begin{array}{l}50,0 \% \\
18,8 \text { a } 81,2 \%\end{array}$ & $\begin{array}{l}100,0 \% \\
64,6 \text { a } 100,0 \%\end{array}$ & $\begin{array}{l}50,0 \% \\
9,5 \text { a } 90,5 \%\end{array}$ \\
\hline Especificidad & $\begin{array}{l}88,46 \% \\
76,18 \text { a } 100,74 \%\end{array}$ & $\begin{array}{l}96,72 \% \\
92,25 \text { a } 101,19 \%\end{array}$ & $\begin{array}{l}61,5 \% \\
42,5 \text { a } 77,6 \%\end{array}$ & $\begin{array}{l}90,3 \% \\
80,5 \text { a } 95,5 \%\end{array}$ & $\begin{array}{l}78,7 \% \\
66,9 \text { a } 87,1 \%\end{array}$ & $\begin{array}{l}97,7 \% \\
87,9 \text { a } 99,6 \%\end{array}$ \\
\hline Valor predictivo positivo & $\begin{array}{l}90,62 \% \\
80,52 \text { a } 100,72 \%\end{array}$ & $\begin{array}{l}75,0 \% \\
44,99 \text { a } 105,00 \%\end{array}$ & $\begin{array}{l}77,3 \% \\
63,0 \text { a } 87,2 \%\end{array}$ & $\begin{array}{l}33,3 \% \\
86,1 \text { a } 19,5 \%\end{array}$ & $\begin{array}{l}35,0 \% \\
18,1 \text { a } 56,7 \%\end{array}$ & $\begin{array}{l}50,0 \% \\
9,5 \text { a } 90,5 \%\end{array}$ \\
\hline Valor predictivo negativo & $\begin{array}{l}63,88 \% \\
48,19 \text { a } 79,57 \%\end{array}$ & $\begin{array}{l}98,33 \% \\
95,09 \text { a } 101,57 \%\end{array}$ & $\begin{array}{l}66,7 \% \\
46,7 \text { a } 82,0 \%\end{array}$ & $\begin{array}{l}94,9 \% \\
86,1 \text { a } 19,5 \%\end{array}$ & $\begin{array}{l}100,0 \% \\
92,6 \text { a } 100,0 \%\end{array}$ & $\begin{array}{l}97,7 \% \\
87,9 \text { a } 99,6 \%\end{array}$ \\
\hline $\begin{array}{l}\text { Consciente de probabilidad } \\
\text { positivo }(\mathrm{CP}+)\end{array}$ & $\begin{array}{l}5,98 \\
2,02 \text { a } 17,68\end{array}$ & $\begin{array}{l}26,14 \\
6,47 \text { a } 105,60\end{array}$ & $\begin{array}{l}2,10 \\
1,27 \text { a } 3,50\end{array}$ & $\begin{array}{l}5,17 \\
1,71 \text { a } 15,58\end{array}$ & $\begin{array}{l}4,69 \\
2,90 \text { a } 7,60\end{array}$ & $\begin{array}{l}21,50 \\
1,99 \text { a } 232,73\end{array}$ \\
\hline $\begin{array}{l}\text { Consciente de probabilidad } \\
\text { negativo (CP-) }\end{array}$ & $\begin{array}{l}0,34 \\
0,21 \text { a } 0,56\end{array}$ & $\begin{array}{l}0,14 \\
0,02 \text { a } 0,90\end{array}$ & $\begin{array}{l}0,31 \\
0,16 \text { a } 0,60\end{array}$ & $\begin{array}{l}0,55 \\
0,24 \text { a } 1,27\end{array}$ & & $\begin{array}{l}0,51 \\
0,13 \text { a } 2,08\end{array}$ \\
\hline
\end{tabular}


Encontramos una concordancia diagnóstica significativa entre la localización del dolor en HCD y el diagnóstico de colecistitis, sin embargo en la literatura revisada sólo en un 38\% de casos de colecistitis el dolor se limita al hipocondrio derecho. Esta localización también resulta significativa en el caso de la apendicitis aguda, en esta, hasta un $74 \%$ de casos presentan dolor confinado a la fosa iliaca derecha en el momento de ingreso por urgencias $(20,21)$.

En cuanto a la correlación con otros síntomas no hemos encontrado diferencias significativas; en una larga serie el $100 \%$ de pacientes con apendicitis, colecistitis y obstrucción intestinal refieren dolor seguido de vómitos en contraste con un 20 y $24 \%$ con dolor abdominal no filiado y gastroenteritis respectivamente. Otros trabajos también apoyan este hecho, así, fiebre y los vómitos son más frecuentes con apendicitis aguda que en las otras causas de abdomen agudo $(22,23)$.

Con respecto a los signos clínicos sólo hemos encontrado una correlación significativa entre la fiebre y la perforación de víscera hueca y entre el signo de Murphy y la colecistitis. La sensibilidad y especificidad encontradas con respecto al signo del psoas son muy similares a las encontradas en otras series en torno al 16 y $95 \%$ respectivamente; siendo algo menores con respecto al Blumberg o signo de rebote que se sitúa en nuestro estudio entorno al 50 y $23 \%$ (24).

La principal indicación del recuento y fórmula leucocitaria es la diferenciación entre apendicitis aguda y dolor abdominal inespecífico. En este sentido, la leucocitosis acompaña a la apendicitis aguda en la mayoría de los casos, algo menos en colecistitis y aproximadamente en la mitad de casos de obstrucción, frente a gastroenteritis en un $43 \%$ y dolor abdominal inespecífico en un 31\% (25).

En cuanto a las pruebas de imagen, la ecografía tiene con respecto a la colecistitis aguda una exactitud diag- nóstica del 95-99\%, siendo para la apendicitis menor entorno a $76 \%$ (25).

La correlación obtenida entre las diferentes pruebas diagnósticas y la laparoscopia es deficiente, así como esta con respecto al gold estándar (confirmación AP), haciéndola sensible, pero ineficiente en cuanto a su especificidad para descartar la patología en cuestión, facilitando la aparición de falsos negativos en cantidad considerable. La laparoscopia puede resultar un instrumento útil para el diagnóstico y posible tratamiento del dolor abdominal agudo, aunque la eficiencia en nuestro estudio es baja, no así en otras series (26).

El patrón de referencia utilizado (hallazgo anatomopatológico de la pieza quirúrgica) sólo puede comprobarse en los pacientes intervenidos, lo que implica un posible sesgo de secuencia (o verification bias). El sesgo de secuencia es habitual cuando el patrón de referencia es una técnica invasiva y tiene más probabilidad de llevarse a cabo cuando la prueba diagnóstica es positiva (ecografía abdominal indicativa de apendicitis). Se ha valorado la fiabilidad de las pruebas diagnósticas sólo en las de imagen, sin haber tenido en cuenta el mismo proceso en la exploración física (27).

\section{CONCLUSIONES}

1. La anamnesis y la exploración física tienen una exactitud limitada a la hora de valorar abdomen agudo.

2. La ecografía presenta con respecto a la apendicitis un índice de concordancia diagnóstica bajo.

3. La laparoscopia puede resultar un instrumento útil para el diagnóstico y posible tratamiento del dolor abdominal agudo, aunque la eficiencia diagnóstica que determinaría su utilización sea baja. 